\title{
Synthesis of a Bis-oxabicyclo[5.4.0] Derivative and their Theoretical Evaluation as a Dopamine, Serotonin Transporters Inhibitor
}

\author{
López-Ramos Maria ${ }^{1(\mathbb{D})}$, Figueroa-Valverde Lauro ${ }^{1, *(\mathbb{D})}$, Díaz-Cedillo Francisco ${ }^{2}{ }^{(\mathbb{D})}$, Rosas-Nexticapa \\ Marcela ${ }^{3(D)}$, Mateu-Armad Maria Virginia ${ }^{3(D)}$, Garcimarrero Alejandara 4 (D), Gutierrez-Lopez \\ Tomas $^{1}{ }^{(1)}$, Alvarez-Ramirez Magdalena ${ }^{3}$ (D), Ortiz-Ake Yazmin ${ }^{1}$ (D) , Cauich-Carrillo Regina ${ }^{1}$ (D) \\ 1 Laboratory of Pharmaco-Chemistry, Faculty of Chemical Biological Sciences, University Autonomous of Campeche, Av. \\ Agustín Melgar s/n, Col Buenavista C.P. 24039 Campeche, Camp., México \\ 2 Escuela Nacional de Ciencias Biológicas del Instituto Politécnico Nacional. Prol. Carpio y Plan de Ayala s/n Col. Santo \\ Tomas, D.F. C.P. 11340, México \\ 3 Facultad de Nutrición, Universidad Veracruzana, Médicos y Odontologos s/n C.P. 91010, Unidad del Bosque Xalapa \\ Veracruz, México \\ 4 Facultad de Medicina, Universidad Veracruzana, Médicos y Odontologos s/n C.P. 91010, Unidad del Bosque Xalapa \\ Veracruz, México \\ * Correspondence: lauro_1999@yahoo.com; lfiguero@uacam.mx;
}

Scopus Author ID 55995915500

Received: 14.10.2020; Revised: 8.11.2020; Accepted: 10.11.2020; Published: 14.11.2020

Abstract: The aim of this investigation was to synthesize a bis-oxabicyclo[5.4.0] derivative (compound 6) was prepared from Fluoro-2,4-dinitrobenzene. The chemical structure of the compounds was determined using nuclear magnetic resonance spectra. Besides, the theoretical activity of compound $\mathbf{6}$ on either dopamine ( $4 \mathrm{~m} 48$ protein) or serotonin (5i6z protein) transporters was evaluated using fluoxetine and altropone as controls in a Docking model. The data found indicate a higher interaction of 6 with 5i6z protein compared with fluoxetine. In addition, 6 could have lower affinity by $4 \mathrm{~m} 48$ protein in comparison with altropone. All data showed that compound 6 could be good dopamine, serotonin transporters inhibitor.

Keywords: oxabicyclo; synthesis; dopamine; serotonin.

(C) 2020 by the authors. This article is an open-access article distributed under the terms and conditions of the Creative Commons Attribution (CC BY) license (https://creativecommons.org/licenses/by/4.0/).

\section{Introduction}

For several years, have been synthesized several dopamine and serotonin transporter inhibitors [1-3]; for example, a series of gamma-amino alcohols were prepared from cyanide and some aldehyde derivatives as dopamine and serotonin inhibitors [4]. Besides, a study showed the synthesis of some thiophene derivatives from several tropane analogs to evaluate their biological activity on catecholamine transporters [5]. Other data indicate the synthesis of some phenyltropane derivatives via reaction of cyclic ketoesters with aryl boronates; it is noteworthy that phenyltropane derivatives were used as dopamine and serotonin transporter inhibitors [6]. In addition, a report showed the synthesis of some cyclopropane analogs from sulfonium ylide as a serotonin transporter inhibitor [7]. Another study showed the preparation of a 3,7-dimethylimipramine via reaction of 3,7-dihydroxymethyl imipramine and Palladium with biological activity on serotonin transporter [8]. All these reports indicate that several compounds have been prepared with biological activity on both dopamine and serotonin 
transporters. Analyzing these data, the objective of this investigation was to prepare a bisoxabicyclo[5.4.0] derivative to evaluate their theoretical activity on either dopamine or serotonin transporters using a docking model.

\section{Materials and Methods}

\subsection{General.}

All reagents used in this research were acquired from Sigma-Aldrich Co., Ltd. The melting point for compounds was evaluated on an Electrothermal (900 model). Infrared spectra (IR) were evaluated with a Thermo Scientific iSOFT-IR spectrometer. ${ }^{1} \mathrm{H}$ and ${ }^{13} \mathrm{C}$ NMR spectra were recorded using a Varian VXR300/5 FT NMR spectrometer at $300 \mathrm{MHz}$ in $\mathrm{CDCl}_{3}$ using TMS as an internal standard. EIMS spectra were obtained with a Finnigan Trace Gas Chromatography Polaris Q-Spectrometer. Elementary analysis data were acquired from a Perkin Elmer Ser. II CHNS/02400 elemental analyzer.

\subsubsection{Synthesis.}

\section{6-(2,4-Dinitro-phenyl)-hex-5-yn-1-ol (2)}

In a round bottom flask $(10 \mathrm{ml}), 1$-Fluoro-2,4-dinitrobenzene $(100 \mu 1,0.79 \mathrm{mmol}), 5$ hexyn-1-ol (100 $\mu 1,0.90 \mathrm{mmol})$, and Copper(II) chloride anhydrous (110 mg, $0.99 \mathrm{mmol})$ were stirred to room temperature at $72 \mathrm{~h}$. Then, the solvent was evaporated under reduced pressure and following the product was purified via crystallization using the methanol:agua (4:1) system; yielding 54\% of product; m.p. 132-134 ${ }^{\circ} \mathrm{C}$; IR $\left(V_{\max }, \mathrm{cm}^{-1}\right) 2190$ and 1542: ${ }^{1} \mathrm{H}$ NMR $\left(300 \mathrm{MHz}, \mathrm{CDCl}_{3}-d\right) \delta_{\mathrm{H}}: 1.56-1.60(\mathrm{~m}, 4 \mathrm{H}), 1.94$ (broad, $\left.1 \mathrm{H}\right), 2.26-3.64(\mathrm{~m}, 4 \mathrm{H}), 7.96-8.36$ $(\mathrm{m}, 3 \mathrm{H}) \mathrm{ppm} .{ }^{13} \mathrm{C} \mathrm{NMR}\left(300 \mathrm{~Hz}, \mathrm{CDCl}_{3}\right) \delta \mathrm{c}: 19.64,25.76,31.82,62.21,80.65,88.70,120.50$, 123.04, 128.00, 137.62, 149.52, 155.03 pm. EI-MS m/z: 264.07. Anal. Calcd. for $\mathrm{C}_{12} \mathrm{H}_{12} \mathrm{~N}_{2} \mathrm{O}_{5}$ : C, 54.55; H, 4.58; N, 10.60; O, 30.28. Found: C, 54.52; H, 4.54.

\section{2-nitro-2-oxabicyclo[7.4.0]trideca-1(13),9,11-trien-7-yne (3)}

In a round bottom flask $(10 \mathrm{ml})$, compound $2(100 \mathrm{mg}, 0.38 \mathrm{mmol})$, potassium carbonate anhydrous (50 $\mathrm{mg}, 0.36 \mathrm{mmol}$ ) and $5 \mathrm{ml}$ of dimethyl sulfoxide were stirred to room temperature at $72 \mathrm{~h}$. Then, the solvent was evaporated under reduced pressure and following the product was purified via crystallization using the methanol:hexane:agua (3:1:1) system; yielding $45 \%$ of product; m.p. $166-168^{\circ} \mathrm{C}$; IR $\left(V_{\max }, \mathrm{cm}^{-1}\right) 2190,1542$ and $1242:{ }^{1} \mathrm{H}$ NMR (300 $\left.\mathrm{MHz}, \mathrm{CDCl}_{3}-d\right) \delta_{\mathrm{H}}: 1.00-3.90(\mathrm{~m}, 8 \mathrm{H}), 7.43-7.70(\mathrm{~m}, 3 \mathrm{H}) \mathrm{ppm} .{ }^{13} \mathrm{C} \mathrm{NMR}\left(300 \mathrm{~Hz}, \mathrm{CDCl}_{3}\right)$ $\delta_{\mathrm{C}}: 20.34,29.80,32.50,67.30,76.72,97.12,111.32,117.42,117.48,134.70,149.70$ pm. EIMS m/z: 217.07. Anal. Calcd. for $\mathrm{C}_{12} \mathrm{H}_{11} \mathrm{NO}_{3}: \mathrm{C}, 66.35 ; \mathrm{H}, 5.10 ; \mathrm{N}, 6.45 ; \mathrm{O}, 22.10$. Found: $\mathrm{C}$, 66.32; H, 5.08 .

\section{2-oxabicyclo[7.4.0]trideca-1(13),9,11-trien-7-yn-12-amine (4)}

In a round bottom flask $(10 \mathrm{ml})$, compound $3(100 \mathrm{mg}, 0.46 \mathrm{mmol})$ sodium borohydride (30 mg, $0.79 \mathrm{mmol}$ ) and $5 \mathrm{ml}$ of ethanol were stirred to room temperature at $72 \mathrm{~h}$. Then, the solvent was evaporated under reduced pressure and following the product was purified via crystallization using the methanol:agua (3:1) system; yielding 68\% of product; m.p. 144-146 ${ }^{\circ} \mathrm{C}$; IR $\left(V_{\max }, \mathrm{cm}^{-1}\right) 3380,2192$ and 1242: ${ }^{1} \mathrm{H}$ NMR (300 MHz, $\left.\mathrm{CDCl}_{3}-d\right) \delta_{\mathrm{H}}: 1.00-3.90(\mathrm{~m}, 8 \mathrm{H})$, 4.84 (broad, 1H), 6.17-6.84 (m, 3H) ppm. ${ }^{13} \mathrm{C} \mathrm{NMR}\left(300 \mathrm{~Hz}, \mathrm{CDCl}_{3}\right) \delta_{\mathrm{C}}: 20.34,29.80,32.50$, 67.30, 76.72, 97.12, 100.22, 105.62, 110.92, 131.14, 150.50 pm. EI-MS m/z: 187.09. Anal. Calcd. for $\mathrm{C}_{12} \mathrm{H}_{13} \mathrm{NO}$ : C, 76.98; H, 7.00; N, 7.48; O, 8.54. Found: C, 76.95; H, 7.00. 


\section{1-[(E)-2-oxabicyclo[7.4.0]trideca-1(13),9,11-trien-7-yn-12-yliminomethyl]- naphthalen-2-ol} (5)

In a round bottom flask $(10 \mathrm{ml})$, compound $4(100 \mathrm{mg}, 0.53 \mathrm{mmol})$ 2hydroxynaphthalene-1-carbaldehyde (100 mg, $0.58 \mathrm{mmol})$, boric acid ( $35 \mathrm{mg}, 0.56 \mathrm{mmol})$ and $5 \mathrm{ml}$ of methanol were stirred to room temperature at $72 \mathrm{~h}$. Then, the solvent was evaporated under reduced pressure and following the product was purified via crystallization using the methanol:agua (4:1) system; yielding $45 \%$ of product; m.p. $182-184{ }^{\circ} \mathrm{C}$; IR $\left(V_{\max }, \mathrm{cm}^{-1}\right) 3400$, 3332, 2190 and 1240: ${ }^{1} \mathrm{H}$ NMR $\left(300 \mathrm{MHz}, \mathrm{CDCl}_{3}-d\right) \delta_{\mathrm{H}}: 1.00-3.90(\mathrm{~m}, 8 \mathrm{H}), 4.84($ broad, $1 \mathrm{H})$, 6.56-6.76 (m, 2H), $6.92(\mathrm{~m}, 1 \mathrm{H}), 7.17(\mathrm{~m}, 1 \mathrm{H}), 7.58-8.54(\mathrm{~m}, 5 \mathrm{H}), 8.90(\mathrm{~m}, 1 \mathrm{H}), 14.78$ (broad, $1 \mathrm{H})$ ppm. ${ }^{13} \mathrm{C} \mathrm{NMR}\left(300 \mathrm{~Hz}, \mathrm{CDCl}_{3}\right) \delta \mathrm{C}: 20.34,29.80,32.50,67.30,76.72,97.12,104.90$, 105.96, 108.30, 114.18. 121.10, 122.73, 123.80, 127.06, 128.60, 128.86, 133.32, 135.50, 136.23, 153.50, 160.94, 163.36 ppm. EI-MS m/z: 341.14. Anal. Calcd. for $\mathrm{C}_{23} \mathrm{H}_{19} \mathrm{NO}_{2}: \mathrm{C}$, 80.92; H, 5.61; N, 4.10; O, 9.37. Found: C, 80.90; H, 5.58.

(E)-N-(2-oxabicyclo[7.4.0]trideca-1(13),9,11-trien-7-yn-12-yl)-1-[2-(2-oxabicyclo[7.4.0]

\section{trideca-1(13),9,11-trien-7-yn-12-yloxy)-1-naphthyl]methanimine (6)}

In a round bottom flask $(10 \mathrm{ml})$, compound $3(65 \mathrm{mg}, 0.30 \mathrm{mmol})$, compound 5 (100 $\mathrm{mg}, 0.29 \mathrm{mmol})$ compound $(100 \mathrm{mg}, 0.58 \mathrm{mmol})$, potassium carbonate anhydrous $(50 \mathrm{mg}$, $0.36 \mathrm{mmol}$ ) and $5 \mathrm{ml}$ of dimethyl sulfoxide were stirred to room temperature at $72 \mathrm{~h}$. Then, the solvent was evaporated under reduced pressure and following the product was purified via crystallization using the methanol:agua (4:1) system; yielding 45\% of product; m.p. 208-210 ${ }^{\circ} \mathrm{C}$; IR $\left(V_{\max }, \mathrm{cm}^{-1}\right) 3330,2190$ and 1242: ${ }^{1} \mathrm{H}$ NMR $\left(300 \mathrm{MHz}, \mathrm{CDCl}_{3}-d\right) \delta_{\mathrm{H}}: 1.00-3.90$ (m, 16 $\mathrm{H}), 6.54-7.16(\mathrm{~m}, 5 \mathrm{H}), 7.24(\mathrm{~m}, 1 \mathrm{H}), 7.46(\mathrm{~m}, 1 \mathrm{H}), 7.66-8.80(\mathrm{~m}, 5 \mathrm{H}), 9.04(\mathrm{~m}, 1 \mathrm{H}) \mathrm{ppm} .{ }^{13} \mathrm{C}$ NMR $\left(300 \mathrm{~Hz}, \mathrm{CDCl}_{3}\right) \delta_{\mathrm{C}}: 20.34,29.80,32.50,67.30,76.72,97.12,104.02,104.90,105.62$, 108.12 , 109.92, 110.12, 113.26, 118.48, 122.92, 123.90, 124.12, 125.72, 127.22, 128.44, 133.42, 134.90, 135.50, 150.41, 157.63, 162.80, 163.78, 165.80, 171.54 ppm. EI-MS m/z: 511.21. Anal. Calcd. for $\mathrm{C}_{35} \mathrm{H}_{29} \mathrm{NO}_{3}$ : C, 82.17; H, 5.71; N, 2.74; O, 9.38. Found: C, 82.14; H, 5.68 .

\subsubsection{Pharmacophore analysis}

The 3D pharmacophore model for compound 6 was determined using LigandScout 4.08 software [9].

\subsection{Theoretical evaluation.}

The interaction of compound 6 with either dopamine (4m48) [10] or serotonin (5i6z) [11] transporter proteins was evaluated using the DockingServer software [12]. In addition, fluoxetine (serotonin transporter inhibitor) [13] and reboxetine (dopamine transporter inhibitor) [14] were used as controls.

\section{Results and Discussion}

Several dopamine and serotonin transporters inhibitors have been synthesized [4-8]; however, several protocols use some reagents which require special conditions. In this research, the compound bis-oxabicyclo[5.4.0] derivative was prepared, and their theoretical activity as dopamine and serotonin transporters inhibitor was evaluated. The first stage was achieved as follows: 


\subsection{Chemistry.}

3.1.1 Preparation of a alkyne derivative.

There are several reports for the displacement of halides through nucleophilic substitution using some reagents such as polymer-supports [15], potassium tert-butoxide [16], $\mathrm{Ru}(\mathrm{II}) \mathrm{OAc}$ [17], $\mathrm{Pt}(\mathrm{II})$ [18], others. In this investigation, compound 2 was synthesized from 5hexyn-1-ol and Copper(II) chloride (Figure 1). The ${ }^{1} \mathrm{H}$ NMR spectrum from 2 showed several signals at 1.56-1.60 and 2.26-3.64 ppm for methylene groups linked to both alkyne and hydroxyl groups; at $1.94 \mathrm{ppm}$ for hydroxyl group; at 7.96-8.36 ppm for phenyl group. ${ }^{13} \mathrm{C}$ NMR spectra display chemical shifts at 19.64-62.21 ppm for methylene groups linked to both alkyne and hydroxyl groups; at 80.65-88.70 ppm for alkyne group; at 120.50-155.03 ppm for phenyl group. Besides, the mass spectrum from 2 showed a molecular ion $(\mathrm{m} / \mathrm{z}) 260.07$.

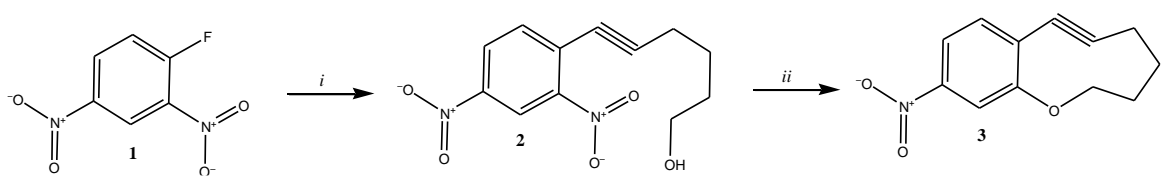

Figure 1. Sinthesis of 12-nitro-2-oxabicyclo[7.4.0]trideca-1(13),9,11-trien-7-yne (3). Conditions and regents: $i=5$-hexyn-1-ol, Copper(II) chloride anhydrous, room temperature, $72 \mathrm{~h} ; i i=$ potassium carbonate anhydrous, dimethyl sulfoxide, room temperature, $72 \mathrm{~h}$.

\subsubsection{Synthesis of an ether-derivative.}

There are methods for the synthesis of ether derivatives, which use some reagents such as $\mathrm{Taa} / \mathrm{Al}_{2} \mathrm{O}_{3}$ [19], palladium [20], tert-Butyl Nitrite [21], Ceric Ammonium Nitrate [22]. In addition, some reports showed the preparation of ether derivatives through the displacement of the nitro group using dipolar aprotic solvents such as dimethyl sulfoxide [23] In this way; in this research, an ether analog (3) was prepared from compound 2, dimethyl sulfoxide, and potassium carbonate (Figure 1). The ${ }^{1} \mathrm{H}$ NMR spectrum from 3 display several signals at 1.00 $3.90 \mathrm{ppm}$ for 1-oxacyclonon-6-yne ring; at 7.43-7.70 ppm for phenyl group. ${ }^{13} \mathrm{C}$ NMR spectra showed chemical shifts at 20.36-67.30 ppm for 1-oxacyclonon-6-yne ring; at 76.72-97.12 ppm for alkyne group; at 111.32-149.70 ppm for phenyl group. Besides, the mass spectrum from 3 showed a molecular ion $(\mathrm{m} / \mathrm{z}) 217.07$.

\subsubsection{Reduction reaction.}

Some methods have used to nitro reduction using some reagents such as stannous chloride [24] $\mathrm{TiO}_{2}$ [25], $\mathrm{Be}_{2}[\mathrm{OH}]_{4}$ [26], graphitic carbon nitride [27], $\mathrm{CuFe}_{2} \mathrm{O}_{4}$ [28], $\mathrm{NiFe}_{2} \mathrm{O}_{4} / \gamma$ $\mathrm{Fe}_{2} \mathrm{O}_{3}[29]$. In this research, compound 4 was prepared via reduction of the nitro group from 3 in the presence of sodium borohydride (Figure 1).

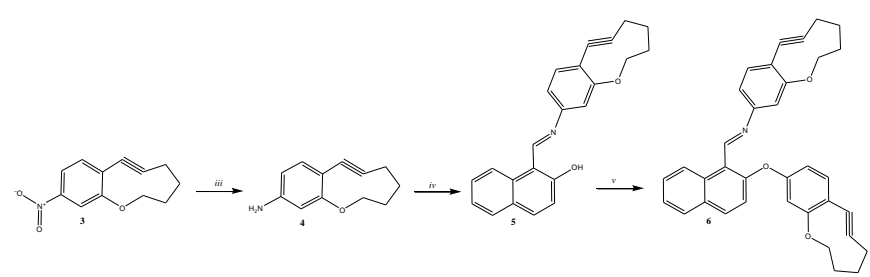

Figure 2. Sinthesis of a bis-oxabicyclo[5.4.0] derivative (6). Conditions and regents: iii = sodium borohydride, $\mathrm{EtOH}$, room temperature, $72 \mathrm{~h} ; i v=2$-hydroxynaphthalene-1-carbaldehyde, boric acid, $\mathrm{MeOH}$, room temperature, $72 \mathrm{~h} ; v=$ compound $\mathbf{3}$, potassium carbonate anhydrous, dimethyl sulfoxide, room temperature, $72 \mathrm{~h}$. 
The ${ }^{1} \mathrm{H}$ NMR spectrum from 4 showed several signals at 1.00-3.90 ppm for 1-oxacyclonon-6-yne ring; at $4.84 \mathrm{ppm}$ for the amino group; at 6.17-6.84 ppm for phenyl group. ${ }^{13} \mathrm{C}$ NMR spectra showed chemical shifts at 20.34-67.30 ppm for 1-oxacyclonon-6-yne ring; at 76.72-97.12 ppm for alkyne group; at 100.22-150.50 ppm for phenyl group. Additionally, the mass spectrum from 4 displays a molecular ion $(\mathrm{m} / \mathrm{z})$ 187.09.

\subsubsection{Preparation of an imino group.}

There are several protocols for preparation of imino groups using some reagents such as Gold(I) [30], AgF [31], chloacetyl acid [32], tert-Butyl hypochlorite [33], dirhodium tetraacetate [34] amd others. In this investigation, an imino derivative was prepared from compound 4 and 2-hydroxynaphthalene-1-carbaldehyde to form compound 5 in the presence of boric acid (Figure 2). The ${ }^{1} \mathrm{H}$ NMR spectrum from 5 showed several signals at 1.00-3.90 ppm for 1-oxacyclonon-6-yne ring; at 6.56-6.76 and 7.17 ppm for phenyl group; at 6.92 and 7.58-8.54 ppm for naphthalene fragment; at $8.90 \mathrm{ppm}$ for imino group; at $14.78 \mathrm{ppm}$ for a hydroxyl group. ${ }^{13} \mathrm{C}$ NMR spectra display chemical shifts at $20.34-67.30 \mathrm{ppm}$ for 1oxacyclonon-6-yne ring; at 76.72-97.12 ppm for alkyne group; at 104.90, 108.30-114.18, 135.50 and $153.50 \mathrm{ppm}$ for phenyl group; at 105.96, 121.10-133.32, 136.23 and $160.94 \mathrm{ppm}$ for naphthalene fragment; at $163.36 \mathrm{ppm}$ for imino group. Besides, the mass spectrum from 5 showed a molecular ion $(\mathrm{m} / \mathrm{z}) 341.14$.

\subsubsection{Synthesis of a second ether group.}

This stage was achieved via a reaction of 3 with 5 to form compound 6 . The ${ }^{1} \mathrm{H}$ NMR spectrum from 6 showed several signals at 1.00-3.90 ppm for 1-oxacyclonon-6-yne ring; at 6.54-6.16 and 7.46 ppm for phenyl group; at 7.24 and 7.66-8.80 ppm for naphthalene fragment; at $9.04 \mathrm{ppm}$ for imino group; at $14.78 \mathrm{ppm}$ for a hydroxyl group. ${ }^{13} \mathrm{C}$ NMR spectra display chemical shifts at 20.34-67.30 ppm for 1-oxacyclonon-6-yne ring; at 76.72-97.12 ppm for alkyne group; at 104.02-110.12, 134.90-150.41, 162.80 and 165.80-171.54 ppm for phenyl group; at 113.26-133.42 and $157.63 \mathrm{ppm}$ for naphthalene fragment; at $163.78 \mathrm{ppm}$ for imino group. Finally, the mass spectrum from 6 showed a molecular ion $(\mathrm{m} / \mathrm{z}) 511.21$.

\subsubsection{Pharmacophore model.}

Several pharmacophore models have been used to predict the interaction of some drugs with different biomolecules in some biological models [35, 36]; In this way. In this investigation, a pharmacophore was prepared for compound 6 (Figure 3, Table 1) using the LigandScout software [9].
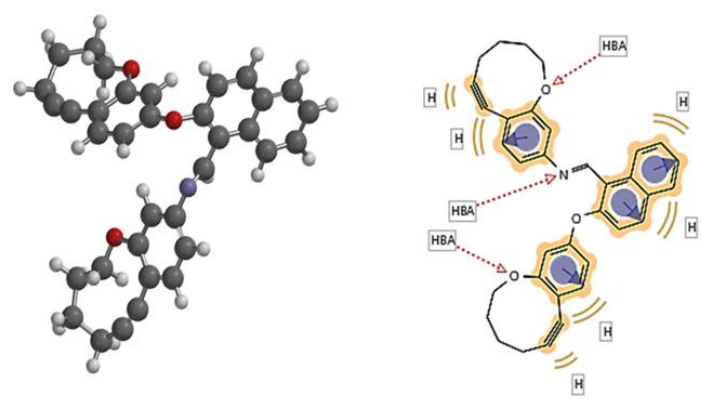

Figure 3. Scheme represents a pharmacophore from compound 6 using the LigandScout software. The model involves a methyl group (yellow) hydrogen bond acceptors (HBA, red). 
Table 1. Physicochemical parameters of compound 6.

\begin{tabular}{|l|l|}
\hline Molecular weight & $511.61 \mathrm{~g} / \mathrm{mol}$ \\
\hline \hline Num. heavy atoms & 39 \\
\hline \hline Num. arom. heavy atoms & 22 \\
\hline \hline Fraction C $\left(\mathrm{sp}^{3}\right)$ & 0.23 \\
\hline \hline Num. rotatable bonds & 4 \\
\hline Num. H-bond acceptors & 4 \\
\hline \hline Num. H-bond donors & 0 \\
\hline \hline Molar Refractivity & 157.63 \\
\hline \hline TPSA & $40.05 \AA^{2}$ \\
\hline
\end{tabular}

\subsubsection{Teorethical evaluation.}

Several studies have been used to evaluate the ligand-protein interaction of some compounds using different theoretical analysis [35]. In this way, a study was carried out to determine the interaction of compound 6 with DA ( $4 \mathrm{~m} 8 \mathrm{~m}$ protein) and $5 \mathrm{HT}$ (5i6z protein) transporter using DockingServer software (Figure 4).

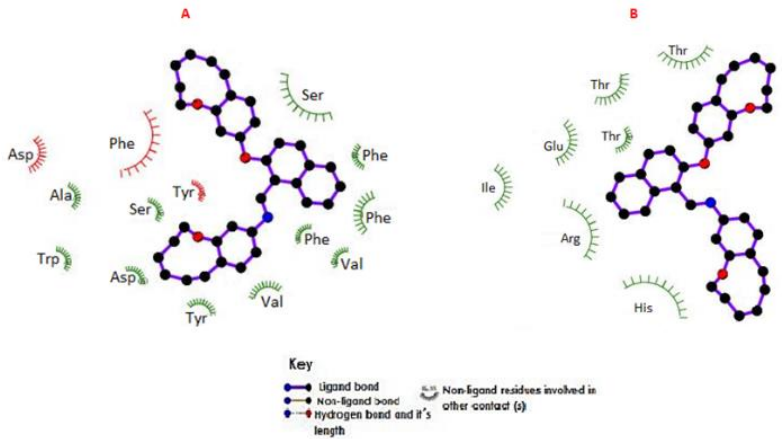

Figure 4. Interaction of compound 6 with either $4 \mathrm{~m} 48$ (A) or 5i6z (B) proteins surface using Dockingserver software.

The data indicated differences in the interaction of fluoxetine, altropone, and compound 6 with either 5i6z and $4 \mathrm{~m} 48$ proteins surface (Table 2 and 3). These data could be due to the energy differences involved in the interaction of compound 6 with either $4 \mathrm{~m} 48$ or $5 \mathrm{i} 6 \mathrm{z}$ proteins.

Table 2. Interaction of either compound 6 or fluoxetine with 5i6z protein.

\begin{tabular}{|c|c|}
\hline Compound & Aminoacid residues \\
\hline \multirow{7}{*}{6} & Thr206 \\
\hline & $\operatorname{Thr}_{225}$ \\
\hline & Glu $_{229}$ \\
\hline & $\operatorname{Thr}_{233}$ \\
\hline & $\operatorname{Arg}_{234}$ \\
\hline & $\mathrm{Ile}_{239}$ \\
\hline & His $_{240}$ \\
\hline \multirow{8}{*}{ Fluoxetine } & $\mathrm{Thr}_{206}$ \\
\hline & Asn208 \\
\hline & Hist 223 \\
\hline & $\mathrm{Thr}_{225}$ \\
\hline & Glu$_{230}$ \\
\hline & Ile $_{239}$ \\
\hline & His 240 \\
\hline & $\mathrm{Tyr}_{487}$ \\
\hline
\end{tabular}

To evaluate the hypothesis above mentioned, a theoretical analysis of energies involved in the interaction of compound 6 with either $4 \mathrm{~m} 48$ or $5 \mathrm{ibz}$ proteins using the Dockingserver software. The results showed (tables 4 and 5) differences in the energies values. Furthermore, 
the $\mathrm{Ki}$ value (inhibition constant) was lower for compound 6 compared with fluoxetine; these data suggest that compound 6 could have a higher affinity for the $5 \mathrm{i} 6 \mathrm{z}$ protein compared to fluoxetine, which could translate as a decrease in the biological activity of the serotonin transporter protein.

Table 3. Interaction of either compound 6 or altropone with $4 \mathrm{~m} 48$ protein.

\begin{tabular}{|c|c|}
\hline Compound & Aminoacid residues \\
\hline \multirow{7}{*}{6} & $\mathrm{Thr}_{206}$ \\
\hline & $\mathrm{Thr}_{225}$ \\
\hline & Glu $_{229}$ \\
\hline & $\operatorname{Thr}_{233}$ \\
\hline & $\operatorname{Arg}_{234}$ \\
\hline & $\mathrm{Ile}_{239}$ \\
\hline & $\operatorname{His}_{240}$ \\
\hline \multirow{11}{*}{ Fluoxetine } & $\mathrm{Phe}_{43}$ \\
\hline & Ala44 \\
\hline & Asp46 \\
\hline & $\mathrm{Val}_{113}$ \\
\hline & Ile $_{116}$ \\
\hline & Ala $_{117}$ \\
\hline & Val $_{120}$ \\
\hline & Asp $_{121}$ \\
\hline & $\operatorname{Tyr}_{124}$ \\
\hline & $\operatorname{Ser}_{320}$ \\
\hline & $\mathrm{Leu}_{321}$ \\
\hline
\end{tabular}

On the other hand, the interaction of compound 6 with protein $4 \mathrm{~m} 48$ showed that the $\mathrm{Ki}$ of compound 6 was higher compared with altropone, which indicates that 6 could exert a lesser effect on the activity of protein $4 \mathrm{~m} 48$ compared to altropone.

Table 4. Energy levels involved in the interaction of compound 6 and fluoxetine with 5i6z protein.

\begin{tabular}{l|l|l|l|l|l|l} 
Compound & $\begin{array}{l}\text { Est. Free } \\
\text { energy of } \\
\text { Binding } \\
(\text { Kcal/mol) }\end{array}$ & $\begin{array}{l}\text { Est. } \\
\text { Inhibition } \\
\text { Constant }(\mathbf{K i}) \\
{[\boldsymbol{\mu M}]}\end{array}$ & $\begin{array}{l}\text { vdW + HBond + } \\
\text { Desolv. Energy } \\
(\text { Kcal/mol })\end{array}$ & $\begin{array}{l}\text { Electrostatic } \\
\text { Energy } \\
(\text { Kcal/mol })\end{array}$ & $\begin{array}{l}\text { Total Inter- } \\
\text { molec. } \\
\text { Energy } \\
(\text { Kcal/mol })\end{array}$ & $\begin{array}{l}\text { Interact. } \\
\text { Surface }\end{array}$ \\
\hline $\mathbf{6}$ & -6.24 & 26.65 & -6.29 & -0.04 & -6.33 & 869.60 \\
\hline Fluoxetine & -4.48 & 519.97 & -5.12 & 0.09 & -5.03 & 476.66
\end{tabular}

Table 5. Type of energies involved in the interaction of compound 6 and altropone with $4 \mathrm{~m} 48$ protein.

\begin{tabular}{l|l|l|l|l|l|l} 
Compound & $\begin{array}{l}\text { Est. Free } \\
\text { energy of } \\
\text { Binding } \\
(\text { Kcal/mol) }\end{array}$ & $\begin{array}{l}\text { Est. } \\
\text { Inhibition } \\
\text { Constant }(\mathbf{K i}) \\
{[\boldsymbol{\mu M}]}\end{array}$ & $\begin{array}{l}\text { vdW + HBond + } \\
\text { Desolv. Energy } \\
(\text { Kcal/mol })\end{array}$ & $\begin{array}{l}\text { Electrostatic } \\
\text { Energy } \\
(\text { Kcal/mol })\end{array}$ & $\begin{array}{l}\text { Total Inter- } \\
\text { molec. } \\
\text { Energy } \\
(\text { Kcal/mol })\end{array}$ & $\begin{array}{l}\text { Interact. } \\
\text { Surface }\end{array}$ \\
\hline $\mathbf{6}$ & -10.96 & 9.28 & -10.94 & 0.05 & -10.89 & 1061.16 \\
\hline Altropane & -7.74 & 2.13 & -8.87 & -0.93 & -9.80 & 700.78
\end{tabular}

\section{Conclusions}

In this study, the synthesis of a bis-oxabicyclo[5.4.0] derivative was reported using some strategies chemical. It's is noteworthy that reagents used in this investigation no require special conditions. Besides, theoretical data showed that compound $\mathbf{6}$ could be good dopamine, serotonin transporters inhibitor.

\section{Funding}

This research received no external funding.

\section{Acknowledgments}

To Benjamin Valverde and Raquel Anzurez, for your unconditional support on this manuscript. 


\section{Conflicts of Interest}

\section{The authors declare no conflict of interest.}

\section{References}

1. Eildal, J.; Andersen, J.; Kristensen, A.; Jørgensen, A.; Bang, B.; Jørgensen, M.; Strømgaard, K. From the selective serotonin transporter inhibitor citalopram to the selective norepinephrine transporter inhibitor talopram: Synthesis and structure-activity relationship studies. Journal of Medicinal Chemistry 2008, 51, 3045-3048, https://doi.org/10.1021/jm701602g.

2. Zhang, H.; Xie, F.; Cheng, M.; Peng, F. Novel Meta-iodobenzylguanidine-Based Copper Thiosemicarbazide-1-guanidinomethylbenzyl Anticancer Compounds Targeting Norepinephrine Transporter in Neuroblastoma. Journal of Medicinal Chemistry 2019, 62, 6985-6991, https://doi.org/10.1021/acs.jmedchem.9b00386.

3. Sakamuri, S.; Enyedy, I.; Kozikowski, A.; Zaman, W.; Johnson, K.; Wang, S. Pharmacophore-based discovery, synthesis, and biological evaluation of 4-phenyl-1-arylalkyl piperidines as dopamine transporter inhibitors. Bioorganic and Medicinal Chemistry Letters 2001, 11, 495-500, https://doi.org/10.1016/S0960894X(00)00703-4.

4. Carlier, P.; Lo, M.; Lo, P.; Richelson, E.; Tatsumi, M.; Reynolds, I.; Sharma, T. Synthesis of a potent widespectrum serotonin-, norepinephrine-, dopamine-reuptake inhibitor (SNDRI) and a species-selective dopamine-reuptake inhibitor based on the gamma-amino alcohol functional group. Bioorganic and Medicinal Chemistry Letters 1998, 8, 487-492, https://doi.org/10.1016/S0960-894X(98)00062-6.

5. Zhou, J.; Kläß, T.; Zhang, A.; Johnson, K.; Wang, C.; Ye, Y.; Kozikowski, A. Synthesis and pharmacological evaluation of (Z)-9-(heteroarylmethylene)-7-azatricyclo [4.3. 1.03, 7] decanes: Thiophene analogues as potent norepinephrine transporter inhibitors. Bioorganic and Medicinal Chemistry Letters 2003, 13, 35653569, https://doi.org/10.1016/S0960-894X(03)00786-8.

6. Petersen, M.; Boye, S.; Nielsen, E.; Willumsen, J.; Sinning, S.; Wiborg, O.; Bols, M. Synthesis, inhibition and binding of simple non-nitrogen inhibitors of monoamine transporters. Bioorganic and Medicinal Chemistry 2007, 15, 4159-4174, https://doi.org/10.1016/j.bmc.2007.03.069.

7. Kozikowski, A.; Zhao, L.; Zhang, A.; Wang, C.; Flippen, J.; Johnson, K. Structural remodeling of cocaine: design and synthesis of trisubstituted cyclopropanes as selective serotonin reuptake inhibitors. ChemMedChem 2006, 1, 58-65, https://doi.org/10.1002/cmdc.200500016.

8. Christensen, H.; Schjøth-Eskesen, C.; Jensen, M.; Sinning, S.; Jensen, H. Synthesis of 3, 7-Disubstituted Imipramines by Palladium-Catalysed Amination/Cyclisation and Evaluation of Their Inhibition of Monoamine Transporters. Chemistry-A European Journal 2011, 17, 10618-10627, https://doi.org/10.1002/chem.201100885.

9. Réau, M.; Langenfeld, F.; Zagury, J.; Montes, M. Predicting the affinity of Farnesoid X Receptor ligands through a hierarchical ranking protocol: a D3R Grand Challenge 2 case study. Journal of Computer-aided Molecular Design 2018, 32, 231-238, https://doi.org/10.1007/s10822-017-0063-0.

10. Penmatsa, A.; Wang, K.; Gouaux, E. X-ray structure of dopamine transporter elucidates antidepressant mechanism. Nature 2013, 503, 85-90, https://doi.org/10.1038/nature12533.

11. Coleman, J.; Green, E.; Gouaux, E. X-ray structures and mechanism of the human serotonin transporter. Nature 2016, 532, 334-339, https://doi.org/10.1038/nature17629.

12. Lauro, F.; Francisco, D.; Marcela, R.; Virginia, M.; Eduardo, P.; Maria, L.; Jhair, C. Preparation of a steroidoxazole-1, 2'-[1,3] oxazete] derivative: biological and theoretical evaluation of its interaction with a kinase protein (CK2). SN Applied Sciences 2019, 1, https://doi.org/10.1007/s42452-019-0378-7.

13. Owens, M.; Knight, D.; Nemeroff, C. Second-generation SSRIs: human monoamine transporter binding profile of escitalopram and R-fluoxetine. Biological Psychiatry 2001, 50, 345-350, https://doi.org/10.1016/S0006-3223(01)01145-3.

14. Penmatsa, A.; Wang, K.; Gouaux, E. X-ray structures of Drosophila dopamine transporter in complex with nisoxetine and reboxetine. Nature Structural and Molecular Biology 2015, 22.

15. Krajnc, P.; Brown, J.; Cameron, N. Monolithic scavenger resins by amine functionalizations of poly (4vinylbenzyl chloride-co-divinylbenzene) PolyHIPE materials. Organic Letters 2002, 4, 2497-2500, https://doi.org/10.1021/o1026115k.

16. Niu, Y.; Sui, G.; Zheng, H.; Shan, H.; Tie, L.; Fu, J.; Kang, Y. Competing Dehalogenation versus Borylation of Aryl Iodides and Bromides under Transition-Metal-Free Basic Conditions. The Journal of Organic Chemistry 2019, 84, 10805-10813, https://doi.org/10.1021/acs.joc.9b01350.

17. Liu, S.; Zhang, S.; Lin, Q.; Huang, Y.; Li, B. Ruthenium (II) Acetate Catalyzed Synthesis of Silylated Oxazoles via $\mathrm{C}-\mathrm{H}$ Silylation and Dehalogenation. Organic Letters 2019, 21, 1134-1138, https://doi.org/10.1021/acs.orglett.9b00085.

18. Wu, W.; Cui, E.; Zhang, Y.; Zhang, C.; Zhu, F.; Tung, C.; Wang, Y. Involving single-atom silver (0) in selective dehalogenation by $\mathrm{AgF}$ under visible-light irradiation. ACS Catalysis 2019, 9, 6335-6341, https://doi.org/10.1021/acscatal.9b01929. 
19. Herrera, C.; Cortes, M.; Larrubia, M.; Domínguez, M.; Díaz, M.; Alemany, L. Dimethyl ether synthesis via methanol dehydration over Ta-supported catalysts. Applied Catalysis A: General 2019, 582, https://doi.org/10.1016/j.apcata.2019.05.022.

20. Chen, X.; Xiao, X.; Sun, H.; Li, Y.; Cao, H.; Zhang, X.; Lian, Z, Yang, S. Transition-Metal-Catalyzed Transformation of Sulfonates via S-O Bond Cleavage: Synthesis of Alkyl Aryl Ether and Diaryl Ether. Organic letters 2019, 21, 8879-8883, https://doi.org/10.1021/acs.orglett.9b02858.

21. Ma, X.; Song, Q. Tert-Butyl Nitrite Mediated Synthesis of Fluorinated O-Alkyloxime Ether Derivatives. Organic letters 2019, 21, 7375-7379, https://doi.org/10.1021/acs.orglett.9b02689.

22. Chavan, S.; Kadam, A.; Lasonkar, P.; Gonnade, R. Synthesis of 3-Azidopiperidine Skeleton Employing Ceric Ammonium Nitrate (CAN)-Mediated Regioselective Azidoalkoxylation of Enol Ether: Total Synthesis of D2 Receptor Agonist ( \pm )-Quinagolide. Organic letters 2018, 20, 7011-7014, https://doi.org/10.1021/acs.orglett.8b02900.

23. Figueroa-Valverde, L.; Rosas, M.; Lopez, M.; Diaz, F.; Mateu, V.; Garcimarrero, A.; Ortiz, Y. Synthesis of a New Dioxaspiro [bicyclo [3.3. 1] nonane-oxabicyclo [6.2. 0] deca-1 (10), 8-dien-4-one Derivative Using Some Chemical Strategies. Letters in Organic Chemistry 2020, 17, 393-402, https://doi.org/10.2174/1570178617666191116123359

24. Bellamy, F.; Ou, K. Selective reduction of aromatic nitro compounds with stannous chloride in non acidic and non aqueous medium. Tetrahedron Letters 1984, 25, 839-842, https://doi.org/10.1016/S00404039(01)80041-1.

25. Zhao, J.; Yin, J.; Zhong, J.; Jiao, T.; Bai, Z.; Wang, S.; Peng, Q. Facile preparation of a self-assembled artemia cyst shell-TiO2-MoS2 porous composite structure with highly efficient catalytic reduction of nitro compounds for wastewater treatment. Nanotechnology 2019, 31.

26. Du, H.; Simmons, N.; Faver, J.; Yu, Z.; Palaniappan, M.; Riehle, K.; Matzuk, M. A mild, DNA-compatible nitro reduction using B2 $(\mathrm{OH})$ 4. Organic Letters 2019, 21, 2194-2199, https://doi.org/10.1021/acs.orglett.9b00497.

27. Krishna, A.; You, J.; Tseng, W.; Dwivedi, G.; Rajesh, N.; Jiang, S.; Tseng, W. Magnetically Separable Nanospherical g-C3N4@ Fe3O4 as a Recyclable Material for Chromium Adsorption and Visible-LightDriven Catalytic Reduction of Aromatic Nitro Compounds. ACS Sustainable Chemistry and Engineering 2019, 7, 6662-6671, https://doi.org/10.1021/acssuschemeng.8b05727.

28. Zeynizadeh, B.; Aminzadeh, F.; Mousavi, H. Green and convenient protocols for the efficient reduction of nitriles and nitro compounds to corresponding amines with $\mathrm{NaBH} 4$ in water catalyzed by magnetically retrievable CuFe 2 O 4 nanoparticles. Research on Chemical Intermediates 2019, 45, 3329-3357, https://doi.org/10.1007/s11164-019-03794-4.

29. El-Subruiti, G.; Eltaweil, A.; Sallam, S. Synthesis of active MFe2O4/ $\gamma$-Fe2O3 nanocomposites (metal= Ni or $\mathrm{Co}$ ) for reduction of nitro-containing pollutants and methyl orange degradation. Nano 2019, 14, https://doi.org/10.1142/S179329201950125X.

30. Xu, W.; Chen, Y.; Wang, A.; Liu, Y. Benzofurazan N-Oxides as Mild Reagents for the Generation of $\alpha-$ Imino Gold Carbenes: Synthesis of Functionalized 7-Nitroindoles. Organic Letters 2019, 21, 7613-7618, https://doi.org/10.1021/acs.orglett.9b02893.

31. Huang, Y.; Nie, J.; Cheung, C.; Ma, J. Silver-Catalyzed [3+ 3] Annulation of Glycine Imino Esters with Seyferth-Gilbert Reagent To Access Tetrahydro-1, 2, 4-triazine-carboxylate Esters. Synlett 2020, 31, 11071111, https://doi.org/10.1055/s-0039-1690894.

32. Metwally, N.; Radwan, I.; El-Serwy, W.; Mohamed, M. Design, synthesis, DNA assessment and molecular docking study of novel 2-(pyridin-2-ylimino) thiazolidin-4-one derivatives as potent antifungal agents. Bioorganic Chemistry 2019, 84, 456-467, https://doi.org/10.1016/j.bioorg.2018.11.050.

33. Tian, X.; Song, L.; Hashmi, A. $\alpha$-Imino Gold Carbene Intermediates from Readily Accessible Sulfilimines: Intermolecular Access to Structural Diversity. Chemistry-A European Journal 2020, https://doi.org/10.1002/chem.201904869.

34. Khaidarov, A.; Rostovskii, N.; Zolotarev, A.; Khlebnikov, A.; Novikov, M. Synthesis of 1-(2-Aminovinyl) indoles and 1, 3'-Biindoles by Reaction of 2, 2-Diaryl-Substituted 2 H-Azirines with $\alpha$-Imino Rh (II) Carbenoids. The Journal of Organic Chemistry 2019, 84, 3743-3753, https://doi.org/10.1021/acs.joc.8b03205.

35. Ng, T.; Rohac, R.; Mitchell, A.; Boal, A.; Balskus, E. An N-nitrosating metalloenzyme constructs the pharmacophore of streptozotocin. Nature 2019, 566, 94-99, https://doi.org/10.1038/s41586-019-0894-z.

36. Pal, S.; Kumar, V.; Kundu, B.; Bhattacharya, D.; Preethy, N.; Reddy, M.; Talukdar, A. Ligand-based pharmacophore modeling, virtual screening and molecular docking studies for discovery of potential topoisomerase I inhibitors. Computational and Structural Biotechnology Journal 2019, 17, 291-310, https://doi.org/10.1016/j.csbj.2019.02.006. 